\title{
Carboxymethylcellulase and $\beta$-Glucosidase Secretion by Protoplasts of Trichoderma reesei
}

\author{
By H. KOLAR, ${ }^{1}$ H. MISCHAK,$^{2}$ W. P. KAMMEL ${ }^{1}$ AND C. P. KUBICEK ${ }^{1 *}$ \\ ${ }^{1}$ Institut für Biochemische Technologie und Mikrobiologie, TU Wien, Getreidemarkt 9 , \\ A-1060 Wien, Austria \\ ${ }^{2}$ Institut für Biochemie Medizinische Fakultät, Universität Wien, Währinger Strasse 17, \\ A-1090 Wien, Austria
}

(Received 3 December 1984; revised 5 February 1985)

\begin{abstract}
Novozym 234, a commercially available enzyme from Trichoderma harzianum, has been used to prepare protoplasts from Trichoderma reesei QM 9414. Optimal conditions were: $20 \mathrm{~h}$ old mycelium, $0.9 \mathrm{M}-\mathrm{KCl}$ as the osmotic stabilizer, $0.1 \%(\mathrm{w} / \mathrm{v})$ Novozym 234 and $18 \mathrm{~h}$ incubation at $28{ }^{\circ} \mathrm{C}$. To prevent damage to the protoplasts during isolation the incubation mixtures were agitated by vibration, so avoiding shaking or stirring. More than $95 \%$ of the protoplasts were viable and were also metabolically intact as shown by their ability to take up $\left[{ }^{14} \mathrm{C}\right]$ leucine and incorporate it into cellular protein. Freshly prepared protoplasts could be induced by sophorose to produce and secrete carboxymethylcellulase and $\beta$-glucosidase. Optimal conditions were: $0.9 \mathrm{M}-\mathrm{KCl}$ as osmotic stabilizer, phosphate buffer $\mathrm{pH} 6.0,7 \mathrm{~mm}$-sophorose and $10^{7}$ protoplasts $\mathrm{ml}^{-1}$. Separation of the secreted proteins by fast protein liquid chromatography revealed at least seven peaks of carboxymethylcellulase activity and $\beta$-glucosidase activity, indicating that some multiplicity of the forms of these enzymes is already present at the secretion stage.
\end{abstract}

\section{INTRODUCTION}

The cellulolytic enzyme system of the filamentous fungus Trichoderma reesei consists of three basic types of enzyme: endo-1,4- $\beta$-glucanase (EC 3.2.1.4), cellobiohydrolase (EC 3.2.1.91) and cellobiase ( $\beta$-glucosidase, EC 3.2.1.21). These enzymes have been found in multiple forms differing in their physicochemical properties (Gum \& Brown, 1977; Okada et al., 1968; Gong et al., 1979; Labudova \& Farkas, 1983). At present it is not known for certain whether this multiplicity arises from multiple genes, low fidelity of translation, post-transcriptional processing, post-secretional modification, or a combination of all these. Some workers have reported evidence for modification of secreted enzymes by proteolytic attack in the culture fluid after secretion (Nakayama et al., 1976; Gong et al., 1979), but this has been challenged by others (Labudova \& Farkas, 1983; Dunne, 1982).

Investigations on extracellular enzyme secretion by filamentous fungi are generally hampered by the fact that the enzymes remain bound to or within the cell wall for some time (Chang \& Trevithick, 1972; Polacheck \& Rosenbeger, 1978; Kubicek, 1981). This precludes the identification of the form of early secreted enzymes. Moreover, this release from the wall may be accompanied or caused by a modification of the protein or its accompanying carbohydrate moiety. Protoplasts should serve as a useful tool in assessing whether cellulolytic enzymes are already secreted in multiple forms. Although Benitez et al. (1975) and recently Picataggio et al. (1983) succeeded in isolating biochemically intact protoplasts from $T$. reesei, they did not investigate these protoplasts with regard to protein secretion.

In the present paper we report the preparation of biochemically intact protoplasts from $T$. reese $i$, which can be induced to secrete cellulases and $\beta$-glucosidases, and present a preliminary analysis of the multiplicity of the early forms of these enzymes. 


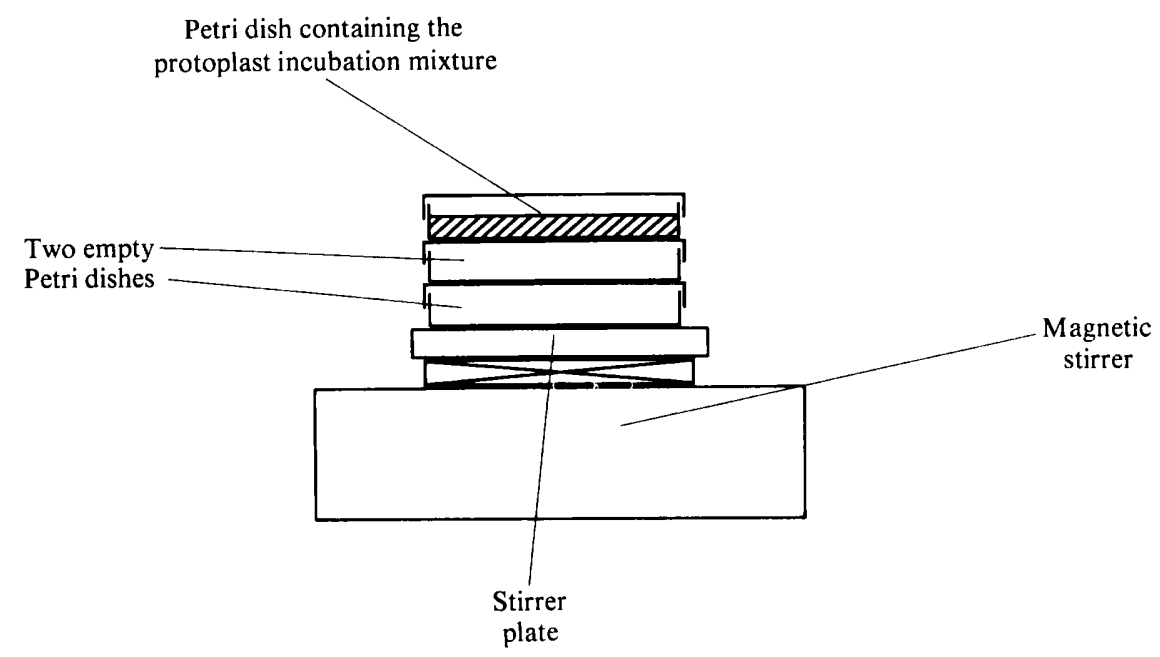

Fig. 1. Schematic drawing of the assembly for the vibration of the protoplast preparation mixture.

\section{METHODS}

Organism and growth conditions. Trichoderma reesei QM 9414 was used throughout these studies. It was kept on malt-agar slants. Inocula were prepared by harvesting $14 \mathrm{~d}$ old conidia in sterile tap water containing $0 \cdot 1 \%(\mathrm{w} / \mathrm{v})$ Tween 80 . These conidia were added to the medium to a final concentration of $10^{8}$ conidia $1^{-1}$. The fungus was grown in shake flasks on a rotary shaker ( 250 r.p.m.) at $28^{\circ} \mathrm{C}$ in the medium described by Mandels \& Andreotti (1978) except that glucose $(0.5 \%, \mathrm{w} / \mathrm{v})$ was used as the carbon source and the $\mathrm{pH}$ of the medium was adjusted to $5 \cdot 0$ with phosphate/citrate buffer as described by Labudova \& Farkas (1983). Samples of this medium (200 ml) were added to 1 litre wide-mouthed Erlenmeyer flasks. The mycelia were removed after appropriate times and used for protoplast isolation as described below.

Isolation of protoplasts. All procedures were performed aseptically. Mycelia from two flasks were harvested by filtration through $\mathrm{G} 1$ glass sinter funnels ( $25 \mathrm{~mm}$ diameter), and were subsequently washed with $200 \mathrm{ml}$ cold $\left(4^{\circ} \mathrm{C}\right.$ ) tap water and $150 \mathrm{ml}$ cold $\left(4^{\circ} \mathrm{C}\right) 50 \mathrm{~mm}$-phosphate buffer, $\mathrm{pH} 6.0$, containing $0.9 \mathrm{M}-\mathrm{KCl}, 0 \cdot 1 \%(\mathrm{v} / \mathrm{v})$ ethanol and $100 \mu \mathrm{g}$ chloramphenicol $\mathrm{ml}^{-1}$. Care was taken that during washing the mycelium was always kept suspended in a minimum of $15 \mathrm{ml}$ of liquid, since otherwise the protoplast yield was considerably reduced. After this washing, the suspension was made up to $20 \mathrm{ml}$ and transferred to a sterile Petri dish. Novozym $234(100 \mathrm{mg})$ was added, and the suspension was stirred with a plastic spatula until the enzyme was completely dissolved. The dishes were then stapled over two empty Petri dishes to provide thermal isolation, and put on a magnetic stirrer plate (see Fig. 1). The slow vibration of the stirrer plate proved the best means of agitating the mycelial digest, since stirring or shaking damaged the protoplasts within a short time. After $18 \mathrm{~h}$ of incubation at $28{ }^{\circ} \mathrm{C}$ the mixtures were filtered through glass wool, and then through a funnel containing (from bottom to top) a layer of milk filter, a layer of cotton and a layer of glass wool. The separation of protoplasts from mycelial debris was checked microscopically; if contaminated the protoplasts were filtered again until they were free from impurities. The protoplasts were then collected by centrifugation at $1000 \mathrm{~g}\left(10 \mathrm{~min}, 4^{\circ} \mathrm{C}\right)$ in a swing-out rotor, and resuspended in an appropriate volume of $50 \mathrm{~mm}$-phosphate buffer, $\mathrm{pH} 6 \cdot 0$, containing $0.9 \mathrm{M} \cdot \mathrm{KCl}$, to give a final concentration of about $10^{7}$ protoplasts $\mathrm{ml}^{-1}$. The viability of the protoplasts was assessed by using Trypan Blue as a vital stain: protoplasts that excluded the dye were considered viable (Hoskins et al., 1956).

Protein synthesis by protoplasts. For measurements of the incorporation of labelled $\left[{ }^{1+C}\right] l$ leucine into trichloracetic acid (TCA) precipitable material, the protoplasts were suspended in $50 \mathrm{~mm}$-phosphate buffer,

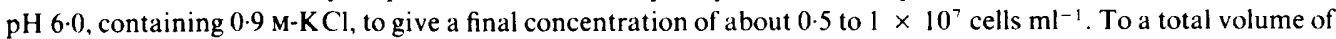
$5 \mathrm{ml}$ protoplast suspension $2.5 \mu \mathrm{Ci}\left[{ }^{14} \mathrm{C}\right]$ leucine $\left(336 \mathrm{mCi} \mathrm{mmol}^{-1}, 124.3 \mathrm{GBq} \mathrm{mmol}^{-1}\right)$ was added, and the mixture incubated at $28^{\circ} \mathrm{C}$. Subsequently, at $30 \mathrm{~min}$ intervals $300 \mu \mathrm{l}$ of the incubation mixture was removed and added to $2 \mathrm{ml}$ of cold $\left(4^{\circ} \mathrm{C}\right) 10 \%(\mathrm{w} / \mathrm{v})$ TCA and then heated in a boiling water bath for $10 \mathrm{~min}$. The insoluble precipitates were collected on $0.22 \mu \mathrm{m}$ membrane filters, washed three times with ice cold $5 \%(\mathrm{w} / \mathrm{v}) \mathrm{TCA}$, and dried. The radioactivity of the dry filters was counted.

Induction of cellulolytic enzyme synthesis in protoplasts. To induce synthesis of cellulolytic enzymes sophorose was added (to give a final concentration of $7 \mathrm{~mm}$ ) to $5 \mathrm{ml}$ protoplast suspension $\left(10^{7}\right.$ protoplasts $\left.\mathrm{ml}^{-1}\right)$. After incubation at $28^{\circ} \mathrm{C}$ for appropriate times, the suspensions were centrifuged in a swing-out rotor at $1000 \mathrm{~g}\left(4^{\circ} \mathrm{C}\right.$, $10 \mathrm{~min}$ ), and the supernatant was kept for enzyme analysis. When the induction of cellulolytic enzymes in whole 
mycelia was studied, essentially the same procedure was used for comparison. Mycelia were used at a concentration of $0.5 \mathrm{~g}$ dry weight $\mathrm{ml}^{-1}$.

Radioactive labelling of exoprotein synthesis. After induction by sophorose, exoprotein synthesis was determined by measuring the incorporation of $\left[{ }^{14} \mathrm{C}\right]$ leucine or $\left[{ }^{14} \mathrm{C}\right]$ mannose into TCA-precipitable extracellular material. Protoplasts ( 1 to $5 \times 10^{7} \mathrm{ml}^{-1}$ ) or mycelia $(0.5 \mathrm{mg}$ dry wt ml-1) were incubated in a total volume of $5 \mathrm{ml} 50 \mathrm{mM}$ phosphate buffer, $\mathrm{pH} 6.0$, containing $0.9 \mathrm{M}-\mathrm{KCl}$. Sophorose was added to give a final concentration of $7 \mathrm{mM}$. After $2 \mathrm{~h}$ incubation at $\left.28^{\circ} \mathrm{C},\left[{ }^{14} \mathrm{C}\right]\right]$ eucine or $\left[{ }^{14} \mathrm{C}\right]$ mannose was added to give final activities of $2 \mu \mathrm{Ci} \mathrm{ml}{ }^{-1}$ $\left(74 \mathrm{kBq} \mathrm{ml}^{-1}\right)$ and $6 \mu \mathrm{Ci} \mathrm{ml}^{-1}\left(222 \mathrm{kBq} \mathrm{ml}^{-1}\right)$ respectively, and the incubation was continued for a further $5 \mathrm{~h}$. The mixtures were then centrifuged in a swing-out rotor $\left(1000 \mathrm{~g}, 4{ }^{\circ} \mathrm{C}, 10 \mathrm{~min}\right)$ and the supernatants withdrawn. TCA $(500 \mathrm{mg})$ was added, and the precipitates were collected on $0.22 \mu \mathrm{m}$ membrane filters and further processed as described above.

Assay of enzyme activities. Endo- $\beta$-glucanase and aryl- $\beta$-glucosidase were assayed as described by Kubicek (1981), with carboxymethylcellulose (Serva, Heidelberg, FRG) or $p$-nitrophenyl $\beta$-D-glucoside as the substrate. The procedures cited by Picataggio et al. (1983) were used for the assay of the hydrolytic enzyme activities of Novozym 234, except for chitinase, which was assayed by the procedure of Monreal \& Reese (1969). One unit (U) of enzyme activity is given as the release of $1 \mu \mathrm{mol}$ glucose equivalent (or respective sugar, as appropriate) $\mathrm{min}^{-1}$. Specific activities are expressed as units of activity $(\mathrm{mg} \text { protein })^{-1}$. Protein was estimated by the Coomassie Blue binding method (Bradford, 1976).

Separation of extracellular proteins by chromatofocusing. Chromatofocusing was done by fast protein liquid chromatography (FPLC) on a Mono P HR 5/20 prepacked column (Pharmacia) at room temperature. The column was equilibrated with $25 \mathrm{~mm}$-Bis-Tris/ $\mathrm{HCl}$ buffer $\mathrm{pH} 7 \cdot 1$. Samples of protein $(0 \cdot 5 \mathrm{mg})$ were dialysed against a 100 fold volume of Bis-Tris/ $\mathrm{NaOH}$ buffer ( $25 \mathrm{~mm}$ ), $\mathrm{pH} 9.0$ (to avoid cellulolysis of the dialysis tube), for $4 \mathrm{~h}$, with two changes of the tube, and finally filtered through $0.22 \mu \mathrm{m}$ membrane filters and applied to the column. A continuous $\mathrm{pH}$ gradient, monitored automatically, was developed by elution with $60 \mathrm{ml}$ polybuffer 74 (Pharmacia) adjusted to $\mathrm{pH} 4.0$ with $\mathrm{HCl}$. A flow rate of $1.0 \mathrm{ml} \mathrm{min}^{-1}$ with an accompanying back pressure of $2.5 \mathrm{MPa}$ was used. Samples of $1.5 \mathrm{ml}$ were collected and assayed for activity.

\section{RESULTS}

\section{Preparation and properties of $T$. reesei protoplasts}

Although Driselase, a hydrolytic enzyme mixture from Irpex lateus, has recently been recommended for protoplast preparation from $T$. reesei QM 6a, RUT-NG 14 and RUT-C 30 (Picataggio et al., 1983), we were unable to isolate protoplasts from T. reesei QM 9414 at an acceptable yield (i.e. more than $10^{5}$ ( $\mathrm{g}$ wet $\left.\mathrm{wt}\right)^{-1}$. Consequently we tested other commercially available lytic enzymes for their suitability for the preparation of $T$. reesei protoplasts. Among these, Novozym 234 - a hydrolytic enzyme from Trichoderma harzianum - proved most successful, and could be used without any additional enzyme supplement. Virtually all additions of other enzymes had either no effect, or even a detrimental effect, on protoplast yield or viability.

In the growth medium we used $T$. reesei germinated after $13 \mathrm{~h}$ incubation and reached the stationary phase of growth after $35-40 \mathrm{~h}$. In accordance with Picataggio et al. (1983), the age of the culture had a pronounced effect on the protoplast yield, the best results being obtained with $20 \mathrm{~h}$ cultures (early growth phase). The optimum concentration of Novozym 234 was $0 \cdot 1 \%$ $(w / v)$. The best osmoticum was $0.9 \mathrm{M} \mathrm{KCl}$ : lower concentrations led to the lysis of some protoplasts. $\left(\mathrm{NH}_{4}\right)_{2} \mathrm{SO}_{4}$ could replace $\mathrm{KCl}$ as an osmoticum, but the subsequent separation of protoplasts by centrifugation was more difficult.

Protoplasts were released from mycelia by extrusion from the apical regions. The mycelium also simultaneously fragmented, apparently at the septa, and protoplasts were extruded from the end of the fragments. Although appreciable formation of protoplasts had already taken place after $3 \mathrm{~h}$ incubation, their complete formation required 16-18 h. A purification protocol for the preparation of protoplasts is given in Table 1 . The recovery of protoplasts was about $20 \%$. The final preparation contained over $99.5 \%$ viable protoplasts, as checked by dye exclusion. The protoplasts were osmotically fragile when the buffer was diluted with water, and they were also destroyed by shearing forces. They were apparently free of cell wall material as checked by phase contrast microscopy. The protoplasts were able to take up $\left[{ }^{14} \mathrm{C}\right]$ labelled leucine and to incorporate it into cellular protein (Fig. 2). 


\section{Table 1. Recovery of protoplasts during preparation}

Protoplast numbers were determined in a counting chamber. The preparation was carried out as described in Methods. The mycelial dry weight at the beginning was $20 \mathrm{mg} \mathrm{ml}^{-1}$.

Fraction

After incubation with Novozym 234

After filtration

After first centrifugation

After second centrifugation

After third centrifugation
Volume (ml)

\section{0}

260

100

50

25
Protoplasts $\mathrm{ml}^{-1}$

$$
\begin{aligned}
& 4.0 \times 10^{7} \\
& 4.6 \times 10^{6} \\
& 1.1 \times 10^{7} \\
& 2.1 \times 10^{7} \\
& 4.0 \times 10^{7}
\end{aligned}
$$

Total protoplasts

$$
\begin{aligned}
& 4.0 \times 10^{9} \\
& 1.2 \times 10^{9} \\
& 1.1 \times 10^{9} \\
& 1.0 \times 10^{9} \\
& 1.0 \times 10^{9}
\end{aligned}
$$

Because Novozym 234, but not Driselase, was effective with $T$. reesei QM 9414 the hydrolytic enzyme activities of both enzyme preparations were compared (Table 2). The only qualitative differences observed were the presence of chitinase and protease in Novozym 234, but not in Driselase. Picataggio et al. (1983) have speculated on the findings that protoplast formation was successful from $T$. reesei QM 6a, RUT-NG 14 and RUT C 30 using an enzyme preparation lacking chitinase. They questioned whether the chitin skeleton might not be formed at this early stage of growth. We have not investigated whether the addition of chitinase to Driselase would induce the formation of protoplasts with $T$. reesei QM 944 . We must further note that the activities of Novozym 234 as assayed in our laboratory, although qualitatively similar, were markedly lower than those reported by Hamlyn et al. (1981), but we cannot offer an explanation for this.

\section{Induction of cellulolytic enzyme synthesis in T. reesei protoplasts}

Cellulase and $\beta$-glucosidase biosynthesis and secretion occurred when $T$. reesei protoplasts suspended in buffer containing an osmotic stabilizer were incubated with the inducing disaccharide sophorose. Although this inducer appears to exert different effects on carboxymethylcellulase and on $\beta$-glucosidase (Sternberg \& Mandels, 1980), we found that approximately the same concentration of sophorose $(7 \mathrm{mM})$ was optimal for the induction of both enzymes (Fig. $3 a$ ). The effect of the pH of the medium and the concentration of osmoticum on the induction of cellulolytic enzymes was also examined (Fig. 3b,c). The high salt concentration apparently inhibited the synthesis of both carboxymethylcellulase and $\beta$ glucosidase; the concentration of $0.9 \mathrm{M}-\mathrm{KCl}$ thus used was a compromise between the effect of lowering of the salt concentration on protoplast lysis and on protein secretion. Other salts (e.g. ammonium sulphate) gave the same effect; polyols, however, were not used, to avoid their use as an energy source by the protoplasts. Addition of other nutrients, especially nitrogen, was not necessary for the induction, which is in accordance with the nutrient requirements of mycelia for induction (Sternberg \& Mandels, 1980). Under the conditions so optimized, protoplasts were shown to synthesize and excrete carboxymethylcellulase, as well as $\beta$-glucosidase, at an approximately linear rate for at least $24 \mathrm{~h}$.

It should be noted that the increase in cellulolytic enzyme activities was not due to binding of the Novozym 234 enzymes to the protoplasts and their subsequent release, since at the beginning of the experiment, less than $5 \%$ of the final activities could be shown to be associated with the protoplast debris.

\section{Identification of early multiple forms}

Although only a small proportion of the total enzyme activity had been secreted during $8 \mathrm{~h}$ incubation, the mixtures were usually withdrawn after this time, and the supernatants used for enzyme separation, since sufficient enzyme had been secreted into the medium to allow its separation by chromatofocusing without prior concentration. Procedures for concentration were avoided since they might result in denaturation of the labile multiple forms which then would not be detectable. However, we were interested in detecting the earliest secreted forms of the enzymes. The chromatofocusing profile (Fig. $4 a$ ) showed that at this stage of cultivation there were already multiple forms of both enzymes, leading to the splitting of both 


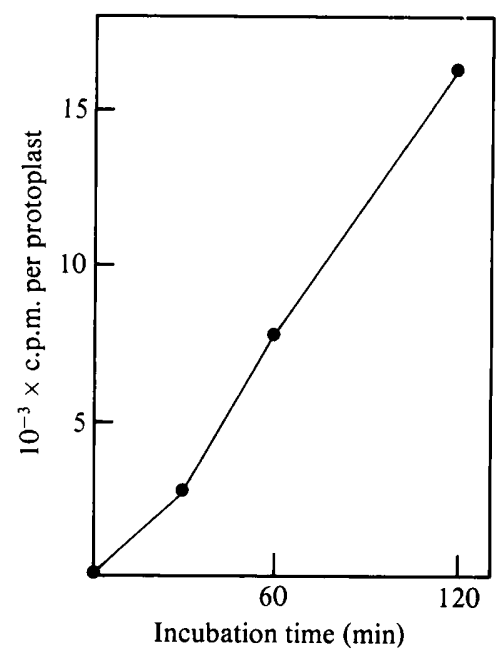

Fig. 2. Incorporation of $\left[{ }^{14} \mathrm{C}\right]$ leucine into intracellular, TCA-precipitable protein. The procedures used were as described in Methods.

\title{
Table 2. Comparison of the enzyme spectrum of Driselase and Novozym 234
}

\begin{abstract}
Enzyme activities were determined as described in Methods. The values for Novozym 234 given in parentheses are from Hamlyn et al. (1981); the value for the protease is a 'trypsin equivalent'. The values for Driselase are from Picataggio et al. (1983).
\end{abstract}

\begin{tabular}{llc}
\multicolumn{1}{c}{ Enzyme } & $\overbrace{\text { Novozym 234 }}^{\left.\text {Specific activity [U (mg protein })^{-1}\right]}$ & Driselase \\
Cellulase & $0 \cdot 0237$ & $0 \cdot 18$ \\
Endo- $\beta$-1,4-glucanase & 0.499 & $114 \cdot 10$ \\
Cellobiase & 0.653 & $0 \cdot 270$ \\
$\beta-1,3-$ Glucanase & $2 \cdot 86(7000)$ & $1 \cdot 23$ \\
$\beta-1,6-$ Glucanase & 0.515 & $0 \cdot 18$ \\
Chitinase & $0.0544(2250)$ & BDL \\
$\alpha$-Mannanase & BDL (0) & BDL \\
$\alpha$-Mannosidase & BDL & BDL \\
Protease & $+++(300)$ & BDL
\end{tabular}

BDL, Below detection limit; +++ , positive result, not quantified.

carboxymethylcellulase and $\beta$-glucosidase activities into at least seven peaks within the $\mathrm{pH}$ range 4 to 7 . With regard to a possible involvement of the cell wall in the origin of the multiple forms normally found in the culture filtrate of $T$. reesei, we initially attempted to compare the secretion profile from protoplasts (Fig. $4 a$ ) with that from cellulase-secreting whole mycelia. The same procedure as with the protoplasts was used, but with intact, washed mycelia. However, under these conditions both carboxymethylcellulase and $\beta$-glucosidase remained bound to the cell wall and were not released into the culture medium within $8 \mathrm{~h}$ (W. P. Kammel, unpublished results). We were thus forced to use a culture filtrate of $T$. reesei grown on cellulose and harvested as early as possible (i.e. after $70 \mathrm{~h}$ cultivation), for comparison (Fig. $4 \mathrm{~b}$ ). Pronounced differences were observed in some of the peaks: it was especially noted that the majority of the carboxymethylcellulase components secreted by protoplasts were found at more acid $\mathrm{pH}$ values than those found in a cellulose-degrading medium. However, the considerable differences in the secretion conditions between the protoplasts and the cellulolytic mycelia precludes an interpretation of these differences in multiple enzyme forms solely on the basis of modification of the enzymes during passage through the cell wall. 

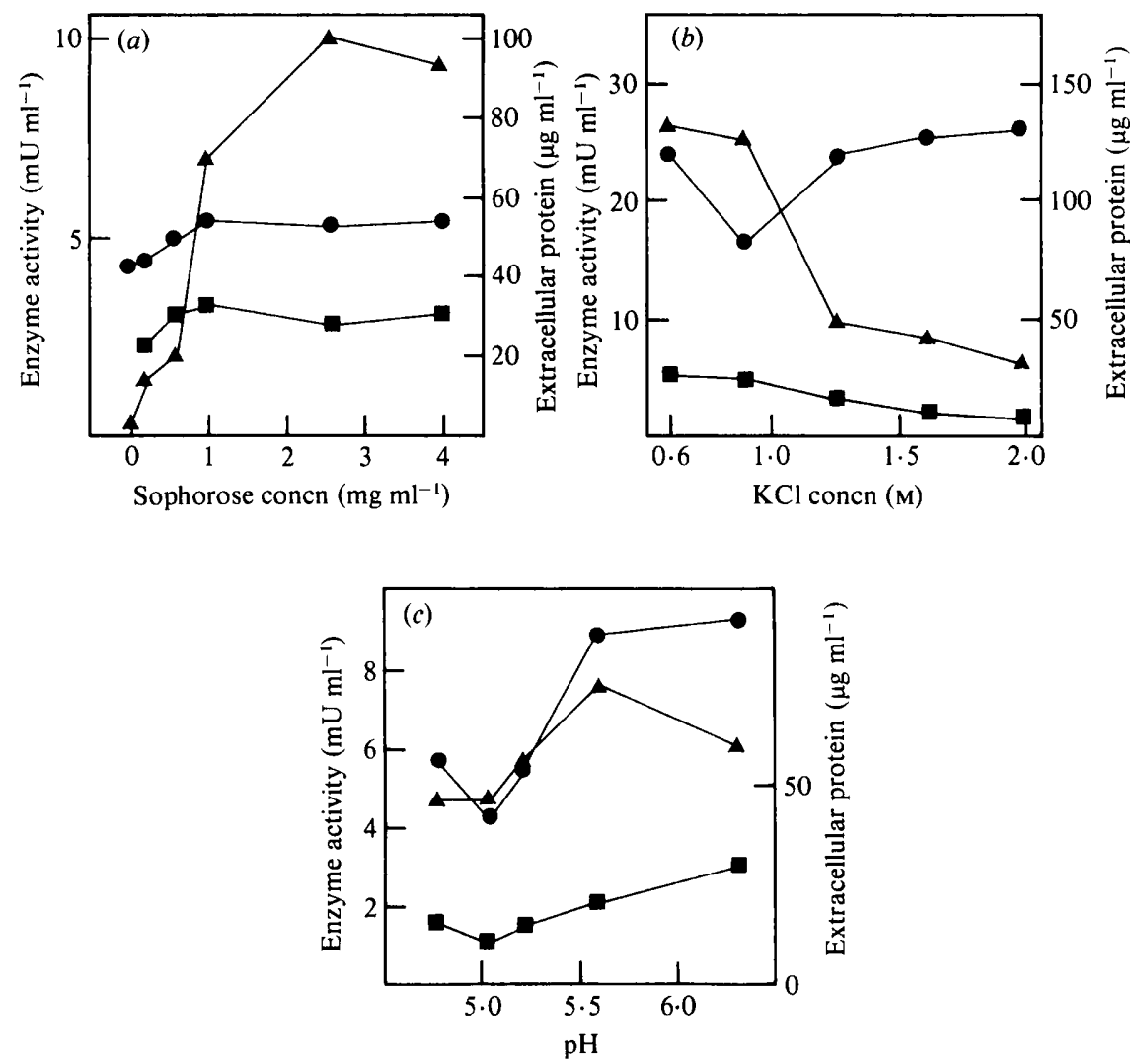

Fig. 3. Influence of sophorose concentration $(a)$, osmoticum concentration $(\mathrm{KCl})(b)$ and $\mathrm{pH}(c)$ on the induction of cellulolytic enzymes and protein in $T$. reesei. $\mathbf{\Lambda}$, Carboxymethylcellulase; $\boldsymbol{\square}, \beta$ glucosidase; extracellular protein. In $(b)$ and $(c)$ the concentration of sophorose was $7 \mathrm{~mm}$. In $(a)$ and $(c)$, enzyme activities were measured after $8 \mathrm{~h}$ incubation; in $(b)$ and $(c)$ they were measured after $20 \mathrm{~h}$ incubation. Experimental conditions were as described in Methods.

What appeared to be actively secreted cellulase and $\beta$-glucosidase could actually have been intracellular enzymes released into the extracellular medium by protoplast lysis, especially since the incubation medium was lacking a nitrogen source. We checked for the occurrence of lysis by several means. Firstly, $\left[{ }^{14} \mathrm{C}\right]$ leucine and $\left[{ }^{14} \mathrm{C}\right]$ mannose were added to the induction media and their incorporation into extracellular, TCA-precipitable protein was followed. The results obtained showed that the secretion of cellulases and $\beta$-glucosidases was accompanied by de novo synthesis and and excretion of glycoproteins. Secondly, protoplasts were harvested after $8 \mathrm{~h}$ induction and lysed by dilution with hypotonic buffer. The intracellular fluid was then assayed for carboxymethylcellulase and $\beta$-glucosidase. No carboxymethylcellulase could be detected (cf. Montenecourt et al., 1981), but $\beta$-glucosidase was present. A separation of intracellular $\beta$ glucosidase by chromatofocusing revealed two peaks of activity, occurring at each extreme of the fractionation range (Fig. 5). Thus the five other $\beta$-glucosidase peaks, at least, could not be due to cell lysis. Finally we checked the distribution of malate dehydrogenase, an essentially intracellular enzyme, which is, however, stable ( $>97 \%$ recovery) at pH 6.0 for $8 \mathrm{~h}$ at $30{ }^{\circ} \mathrm{C}$. The protoplast lysates had high malate dehydrogenase activity (260 units), but less than 0.060 units were detected in the extracellular fluid. We thus conclude that our protoplast system was apparently free of lysing cells, and that the multiple forms detected must represent actively secreted protein species. 

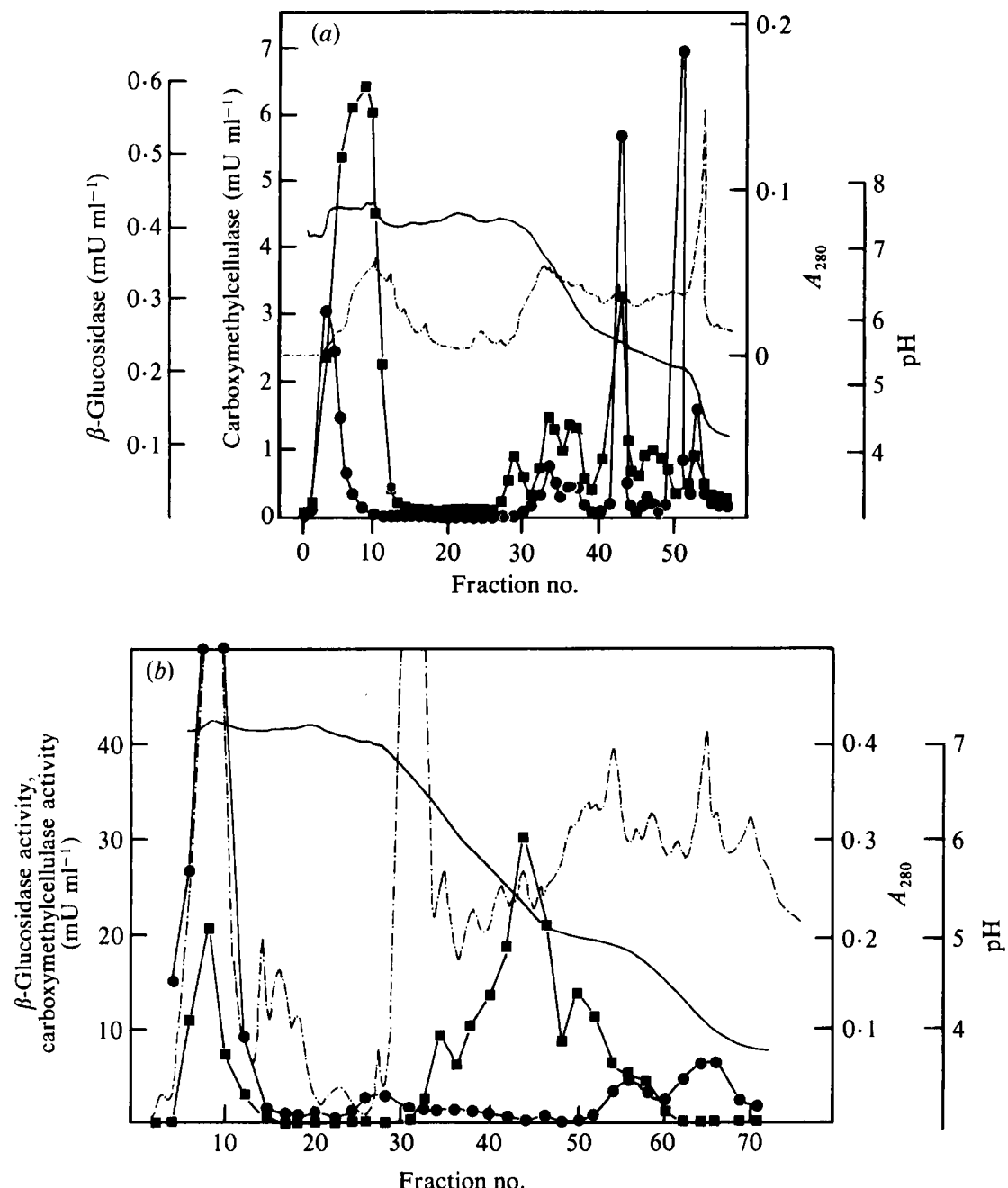

Fig. 4. Chromatofocusing of enzymes secreted by protoplasts $(a)$ and whole mycelia $(b)$, as described by Labudova \& Farkas, 1983. —, Carboxymethylcellulase;,$\beta$-glucosidase. $\_$, pH; ;..-, protein profile $\left(\boldsymbol{A}_{280}\right)$ (both determined continuously).

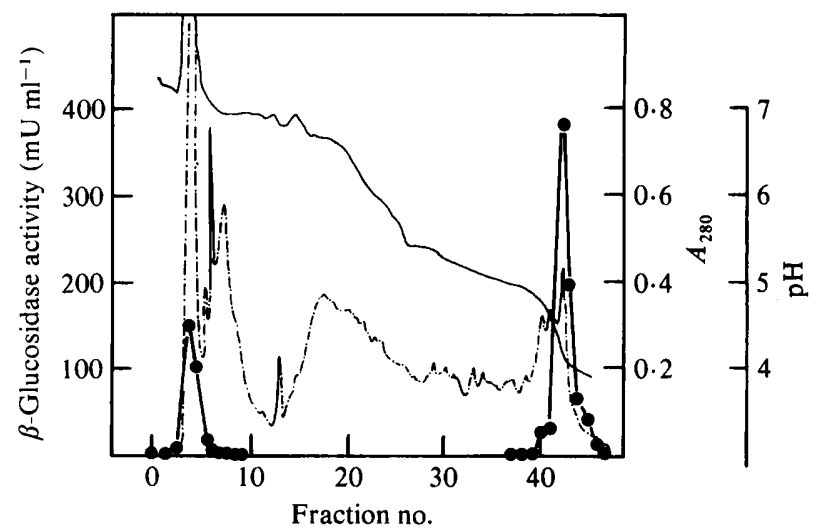

Fig. 5. Chromatofocusing of intracellular $\beta$-glucosidase from $T$. reesei. For symbols see Fig. 4(a) legend. 


\section{DISCUSSION}

Since many secretory proteins of fungi remain bound to the cell wall, protoplasts have been valuable for studying secretion by yeasts (cf. Liras \& Gascon, 1971; Sanchez et al., 1982; Novick \& Scheckman, 1979; Esmon et al., 1984). In contrast, little use has been made of protoplasts of filamentous fungi in such studies; a paper by Trevithick \& Metzenberg (1964), describing invertase secretion by Neurospora crassa protoplasts, appears to be the only exception of this generalization. This is surprising since the preparation of protoplasts from filamentous fungi is feasible using commercially available enzymes (Hamlyn et al., 1981). At the beginning of these investigations we screened a number of available preparations, among which Novozym 234 proved to be best suited for isolating a large number of viable protoplasts from $T$. reesei QM 9414.

The multiplicity of forms of cellulolytic enzymes has been described several times (Gum \& Brown, 1977; Okada et al., 1968; Gong et al., 1979; Labudova \& Farkas, 1983). Our findings that the multiple forms are already found among the proteins secreted within $8 \mathrm{~h}$ by protoplasts supports the assumption (Labudova \& Farkas, 1983; W. P. Kammel \& C. P. Kubicek, unpublished work) that they do not originate by post-secretional modification, although it remains theoretically possible that this modification is completed within that time. The present results do not support the possibility that some of the multiple forms represent enzyme molecules bound to incompletely degraded substrate (cellulose); although such a binding might occur, it seems to contribute little to the occurrence of multiple forms, since they also exist in the absence of an insoluble substrate (i.e. during induction in protoplasts). However, neither do the results obtained support the idea that some of the multiple forms arise during their traverse of the cell wall. This conclusion, however, is not completely justified since we failed to obtain extracellular protein secretion into the culture fluid from whole mycelia under comparable conditions. The occurrence of some multiple forms with different isoelectric points in the culture filtrate from cellulose-degrading $T$. reesei could also be due to the different induction potential of cellulose relative to sophorose. However, this would only be valid if it were assumed that all the multiple forms are genetically determined, which has yet to be proved. Although the present results do not allow any conclusions as to the chemical and structural basis of the multiplicity of the cellulases of $T$. reesei, one result is noteworthy: several of the multiple forms secreted by $T$. reese $i$ protoplasts contained carboxymethylcellulase and $\beta$-glucosidase in the same fraction. This is reminiscent of the model proposed by Sprey \& Lambert $(1983,1984)$ which suggested that multiplicity of cellulases is - at least in part - caused by formation of multienzyme aggregates. The isoelectric points of the activity peaks from the protoplast experiments were quite similar to those of Sprey \& Lambert (1984). It is interesting that both the coincidences of isoelectric points as well as the concomitant appearance of carboxymethylcellulase and $\beta$-glucosidase were far less apparent in cellulose-grown culture filtrates. A theoretical explanation for this observation can be derived from the assumption that cellulolytic enzymes are secreted as multienzyme aggregates into the periplasmic space (Sprey \& Lambert, 1983); because of the high affinity of some of these enzymes for some cell wall polymers (Dickerson \& Baker, 1979), these enzymes might be 'filtered' out of the aggregates, thus giving rise to the new isoelectric points of the aggregates which appear in the extracellular culture fluid. We are currently studying the protein composition of the multiple cellulases secreted by protoplasts in order to check this hypothesis.

The authors are indebted to P. Gruendler, Institut für Biochemie der Medizinischen Fakultät, Vienna, for his help with autoradiography of labelled extracellular proteins. They also appreciate helpful discussions with Dr V. Farkas, Bratislava. Czechoslovakia. This work was supported by grant P 5423 of the Fond zur Förderung der Wissenschaftlicher Forschung. The authors are grateful to Novo Industries for the generous gift of Novozym 2.34

\section{REFERENCES}

Benitez, T., Ramos, S. \& Garcia ACHa, I. (1975). Protoplasts from Trichoderma viride. Formation and regeneration. Archives of Microbiology 103, 199. 203 .
BRADFORD, M. M. (1976). A rapid and sensitive method for the quantitation of microgram quantities of protein utilizing the principle of protein-dye binding. Analytical Biochemistry 72, 248-254. 
Chang, P. L. Y. \& Trevithick, J. R. (1972). Release of wall-bound invertase and trehalase in Neurospora crassa by hydrolytic enzymes. Journal of General Microbiology 70, 13-22.

Dickerson, A. G. \& Baker, R. C. F. (1979). The binding of enzymes to fungal $\beta$-glucans. Journal of General Microbiology 112, 67-75.

DunNe, C. P. (1982). Relationship between extracellular proteases and the cellulase complex of Trichoderma reesei. In Enzyme Engineering, vol. 6, pp. 355-356. Edited by I. Chibata, S. Fukui \& L. B. Wingard, Jr. New York \& London: Plenum Press.

ESMON, B., Esmon, P. C. \& SCHEKMAN, R. (1984). Early steps in the processing of yeast glycoproteins. Journal of Biological Chemistry 259, 10322-10327.

Gong, C.-S., Ladisch, M. R. \& TsaO, G. T. (1979). Biosynthesis, purification and mode of action of cellulases of Trichoderma reesei. Advances in Chemistry Series 105, 261-287.

GuM, E. K. \& Brown, R. D., JR (1977). Comparison of four purified extracellular 1,4- $\beta$-D-glucan cellobiohydrolase enzymes from Trichoderma viride. Biochimica et biophysica acta 492, 225-231.

Hamlyn, P. F., Bradshaw, R. E., Millan, F. M. Santiago, C. M., Wilson, J. M. \& Peberdy, J. F. (1981). Efficient protoplast isolation from fungi using commercial enzymes. Enzyme Microbial Technology 3, 321-325.

Hoskins, J. M., Meynell, G. G. \& Sanders, F. K. (1956). A comparison of methods for estimating viable counts of a suspension of tumour cells. Experimental Cell Research 11, 297-304.

K UBICEK, C. P. (1981). Release of carboxy-methylcellulase and $\beta$-glucosidase from cell walls of Trichoderma reesei. European Journal of Applied Microbiology and Biotechnology 13, 226-231.

Labudova, I. \& Farkas, V. (1983). Multiple enzyme forms in the cellulase system of Trichoderma reese during its growth on cellulose. Biocimica et biophysica acta 744, 135-140.

LiRas, P. \& Gascon, S. (1971). Biosynthesis and secretion of yeast invertase. Effect of cycloheximide and 2-desoxiglucose. European Journal of Biochemis$\operatorname{try} \cdot 23,160 \cdot 165$.

Mandels, M. \& Andreotti, R. E. (1978). Problems and challenges in the cellulose to cellulase fermentation. Process Biochemistry 13, 6-13.

Monreal, J. \& ReEse, E. T. (1969). The chitinase of Serratia marcescens. Canadian Journal of Microbiology 15, 689-696.
Montenecourt, B. S., Nhlapo, S. D., TriminoVasquez, H., Cuskey, S., Schamhart, D. H. J. \& EVELEIGH, D. E. (1981). Regulatory controls in relation to overproduction of fungal cellulases. In Trends in the Biology of Fermentations for Fuels and Chemicals, pp. 33-53. Edited by A. Hollaender \& R. Rabson. New York: Plenum Press.

NaKayama, M., Tomita, Y., SUZuki, H. \& NishizaWA, K. (1976). Partial proteolysis of some cellulase components from Trichoderma viride and the substrate specificity of the modified products. Journal of Biochemistry 79, 955-966.

Novick, P. \& ScheKman, R. (1979). Secretion and cellsurface growth are blocked in a temperaturesensitive mutant of Saccharomyces cerevisiae. Proceedings of the National Academy of Sciences of the United States of America 76, 1858-1862.

Okada, G., Nisizawa, K. \& Suzuki, H. (1968). Cellulase components of Trichoderma viride. Journal of Biochemistry 63, 591-607.

Picataggio, S. K., Schamhart, D. H. J., MonteneCOURT, B. S. \& Eveleigh, D. E. (1983). Sphaeroplast formation and regeneration in Trichoderma reesei. European Journal of Applied Microbiology and Biotechnology 17, 121-128.

Polacheck, I. \& Rosenberger, R. F. (1978). Distributions of autolysins in hyphae of Aspergillus nidulans: evidence for a lipid-mediated attachment to hyphal walls. Journal of Bacteriology 135, 741-747.

Sanchez, A., Villanueva, J. R. \& Villa, T. G. (1982). Effect of tunicamycin on exo-1,3- $\beta$-D-glucanase synthesis and secretion by cells and protoplasts of Saccharomyces cerevisiae. Journal of General Microbiology 128, 3051-3060.

Sprey, B. \& LamberT, C. (1983). Titration curves of cellulases from Trichoderma reesei: demonstration of a cellulase-xylanase- $\beta$-glucosidase containing complex. FEMS Microbiology Letters 18, 217-222.

SPREY, B. \& LAMBERT, C. (1984). Heterogeneity of cellulase complexes from Trichoderma reesei: a preparative isoelectric focusing study of some extracellular hydrolases. FEMS Microbiology Letters 23, 227-232.

SternberG, D. \& Mandels, G. R. (1980). Regulation of the cellulolytic system in Trichoderma reesei by sophorose. Journal of Bacteriology 144, 1197-1199.

Trevithick, J. R. \& Metzenberg, R. L. (1964). The invertase isoenzymes formed by Neurospora protoplasts. Biochemical and Biophysical Research Communications 16, 319-325. 